\title{
Raising Institutional Awareness and Pedagogical Sensitivity: An Analysis of College Faculty Participation in SEED Training
}

\author{
Roshawnda A. Derrick \\ Pepperdine University \\ Kindy DeLong \\ Pepperdine University \\ Cari Myers \\ Pepperdine University
}

\begin{abstract}
Seeking Educational Equity and Diversity (SEED) is a national, peer-led professional development program that promotes change through self-reflection and interpersonal dialogue, with the goals of widening and deepening school and college curricula and making communities more inclusive. This study examines a Christian university in the coastal Western United States which is currently in the fifth year of its own version of SEED conversations involving over fifty percent of the college's full-time faculty. In order to assess the outcomes of SEED training, the authors conducted a survey of faculty who completed the program. This paper will present an overview of the benefits and issues with SEED training for faculty in higher education and discuss preliminary results of the SEED program assessment.
\end{abstract}

Keywords: SEED training, faculty diversity training, diversity and inclusion

\section{INTRODUCTION}

Over the past 50 years, higher education institutions have contended with the diversification of their institutional climates. In this capacity, both the faculty and student bodies have become more diverse in race, class, gender and accessibility needs (U.S. Department of Education; 2016). In fact, studies of postsecondary education reveal increased enrollment rates for students of color, particularly Hispanic students and women continue to make up $56 \%$ of the undergraduate population (National Center for Education Statistics 2019). In addition to the diversification of the US higher education climate in regards to race and gender, institutions must also consider and address inclusion related to LGBTQ+ students and those with accessibility needs. For example, Garvey \& Rankin (2015) pointed out that students who identify as LGBTQ+ are interested in classroom climates that promote a sense of acceptance and support, a critical factor they consider related to college choice. Furthermore, students with disabilities are directly asking institutions to find ways to create a more agile and informed pedagogical space (Morina et al., 2015).

As a result of the varying needs of today's students, postsecondary institutions must consider with more attention: their hiring practices, their ability to accommodate students, faculty and staff, and the importance 
of course materials that explore issues of social identity, social justice and an awareness of others (Ancis, \& Sedlacek, Mohr 2000; Prater, \& Devereaux 2009). To address the inclusion of more diverse class offerings, many higher education institutions have begun to require their students to meet certain diversity requirements to graduate (Humphreys 1997).

Though the typical student body has diversified in the US over the past 50 years, the diversification of college faculty has not shifted at the same rates, as $76 \%$ of postsecondary faculty are white and $53 \%$ are male (U.S. Department of Education, 2017). Thus, when considering the diversity requirements that undergraduate students are to meet, it is important to consider the collective knowledge and professional development opportunities available to faculty members outside of the expertise they possess within their disciplines of study.

In order to meet the needs of a diverse student population then, many researchers have pointed out the significance of faculty diversity training and the inclusion of a nondiscriminatory (and anti-racist) pedagogy in the university classroom (Blakeney 2005; Horsford, Grosland, and Gunn 2011). Students have also started to demand faculty diversity training across the country in recent protests causing universities to consider faculty diversity training programs (Hartwell 2015). Though scholars have noted the limited knowledge on the effectiveness of faculty diversity training programs, the recent protests on college campuses have compelled higher education institutions to invest university resources into faculty diversity training (Clark 2011; Sue et al, 2009).

Related to faculty diversity training, Bezukova et al.'s (2012) conclusions point out that there has not been much research on "participants characteristics and how they relate to the training itself, to the trainer, and to the fellow participants" (222). In this context then, we examine a voluntary diversity training program for faculty carried out at a Christian university in the coastal Western United States, called the National SEED (Seeking Educational Equity and Diversity) project, which spans an academic year (SeptemberApril). We analyze the collective responses of the faculty members that have participated in the program over the past four years. This study is particularly interested in how the college's implementation of the SEED program has impacted faculty member's course design and curriculum, and adds to the current literature on faculty diversity training in higher education institutions.

\section{LITERATURE REVIEW}

As mentioned above, the collective population of postsecondary faculty members has not racially diversified to the same extent as the student bodies found around the country at institutions of higher education. Consequently, many universities are asking their faculty members to teach with nondiscrimintaory and anti-racist pedagogies and to also expose students to vocabulary and materials that exemplify an awareness of other social groups. As a result, many faculty members feel unprepared or timid about addressing issues around diversity and inclusion in the classroom (Sciame-Giesecke, Roden \& Parkinson, 2009; Tatum, 1992), as they have not received the appropriate professional development.

Likewise, multiple pedagogical researchers have concluded that college faculty need effective diversity training (Booker, Merriweather \& Campbell-Whatley, 2016; Boysen, Vogel, Cope \& Hubbard, 2009; Boysen, 2012; Caplan \& Ford, 2014; Jones, 2017; Marcus, Mullins, Brackett, Tang, Allen \& Pruett, 2003; Minikel-Lacocque, 2013; Samuels, 2014; Sue, Lin, Torino, Capodilupo \& Rivera, 2009; Torres, HowardHamilton \& Cooper, 2003). Effective diversity training allows faculty members to feel confident in interacting with these topics in a university setting, to model non-discriminatory language and behavior, and to adequately prepare students to work in multicultural professional workplaces (Burnell \& Schnackenberg, 2015; Goldstein Hode, Behm-Morawitz \& Hays, 2018; Jones, King, Nelson, Geller \& Bowes-Sperry, 2013; Rogers-Sirin \& Sirin, 2009). However, for a variety of reasons, much of the training available does not necessarily prepare educators to teach in multicultural settings. For example, singular, brief diversity training programs that last less than a day tend to be less effective over time (Bezrukova et al., 2016; Chrobot-Mason \& Quinones, 2002; Noe, 2010). In fact, one-time training over a brief period (a day or a weekend) has the opposite effect if it is mandatory, and might increase or exacerbate racial bias (Dobbin \& Kaley, 2016). According to the literature, voluntary, multiple-session training over a series of 
weeks or months is most effective in providing college faculty with the tools to develop a multicultural awareness and sensitivity in the courses they teach (Campbell-Whatley, Merriweather, Lee \& Toms, 2016; Clark, 2005; Goldstein Hode et al., 2018; Hudson, 2020; Mayo \& Larke, 2010; Potthoff, Dinsmore \& Moore, 2001; Waite \& Colvin, 2018).

In March 2020, Nancie J. Hudson published a study evaluating the effectiveness of TIDE (Teaching Inclusion and Diversity Everywhere) as a faculty diversity training tool at her western university. This ethnographic study largely used participant observation but also included 16 participant surveys. While our study bears some marked differences from Hudson's study regarding participation and methodology of the surveys, author positionality, detail of diversity training program, campus climate, and participant perspective, this study supports several of Hudson's findings regarding impact and success of diversity training.

In the present article, we examine the SEED program at a coastal western university, as it exemplifies a voluntary diversity training program designed to affect long-term, personal change in faculty members who are dedicated to multicultural inclusion. To date, there is a lacuna in the literature related to the outcomes of the effects of SEED multicultural and diversity training for faculty, and how this training influences the climate of the overall campus. There has been a substantial body of research examining the effects of diversity courses for students (Consoli \& Marin, 2016; Hurtado et al., 2012; Waterman, 2013) as well as substantial research exploring the effects of diversity training on the secondary level (Hudson 2020, Hicks et al. 2008; O'Hara \& Pritchard 2008). There is likewise no shortage of literature calling for the need for increased diversity training for postsecondary faculty (Hagan \& McGlinn, 2004; Lewis, 2010; Pothoff et al., 2001) or examining the success of various methods of faculty diversity training (Booker et al., 2016; Ceo-DiFrancesco et al., 2019). The literature exploring the impact of SEED training is largely based on personal reflection (Gordon, 2015; Mahabir, 2015) or on the secondary level (Deshmukh et al., 2007; Hicks et al., 2008; O'Hara \& Pritchard, 2008). Therefore, with an interest in effective postsecondary faculty diversity training and the impact of professional development on course design and curriculum, this paper analyzes the college's faculty participation in SEED.

\section{THE SEED PROJECT: FACILITATORS, FUNDING AND THE COLLEGE FACULTY}

To give some background on the program, the National SEED Project developed out of seminars held at Wellesley College in the 1970s and 80s. In 1987, the National SEED project began to offer week-long training for educators. It has trained over $2,700 \mathrm{~K}-12$ teachers, as well as facilitators and representatives from about 100 colleges and universities. The SEED methodology involves structured, group conversations with equitable participation of all voices, examination of how individual stories relate to social systems, and learning from participants' lives as well as texts. While participants respond to short readings or videos, the program is more experiential than theoretical, and offers limited content in the sense of lengthy readings or lectures. The program's goal is to turn oppression and privilege into agency and action (NationalSeedProject.org).

When the college initiated the SEED program, a call was sent out soliciting faculty members to apply to be facilitators. Those who responded were sent to the National SEED Project's week-long facilitator training. Each year, experienced facilitators are invited to return to lead the workshops and the college cycles in one or more facilitators as needed. The new facilitators that cycle in are usually SEED alumni who volunteer or have been recommended by trained facilitators. To date, between the academic years 2016-2017 and 2020-2021, there have been 18 facilitators trained to lead the SEED workshops; thirteen of them have led for one or more years. In the academic year 2019-2020, the college decided to do in-house training (rather than the national training) because slots for the national program were filled. In the academic year 2020-2021, this continued due to the COVID-19 pandemic. As a result, the college has launched a facilitator-in-training program for new facilitators who want to cycle in gradually to the program. In the 2020-2021 academic school year there are 8 facilitators and one in-training facilitator for 65 participants.

In regards to the monthly modules incorporated in the college's SEED workshops, after the national training, during the latter part of the summer, the facilitators attend a planning retreat to work together to 
create a version of SEED most appropriate to the college's context. This adaptation involves choices about which SEED topics and exercises made the most sense for faculty at the institution and the integration of the university's Christian mission with the National SEED material by creating additional facilitator material and discussion questions and by incorporating devotionals and a guest speaker (during the fall retreat). In addition to the planning retreat to create an overview of the topics for the academic year, facilitators meet one or two weeks before each session to frame their organization of the workshop in regards to the topics, pedagogical resources they will employ and the presentational layout of the session.

As the SEED program began, the college administration and college Faculty Association revised the weekly faculty meeting schedule so that faculty could participate without conflicts and recruited participants through correspondence and word of mouth. The SEED program is voluntary and requires faculty members to commit to attending for the academic year (September-April). The facilitators model their monthly workshops around the following predominant topics: individual stories, multiculturalism, racism (typically spanning two workshops), sexuality, and implications for institutional change. There is also a Saturday retreat in the fall for each cohort, as well as a culminating banquet at the end of the academic year. Before each session, the facilitators send a reminder email out to faculty members with pertinent information as well as a short assignment which could include: a short reading or two, a video clip to watch or a quick journaling session to complete before the workshop. In session, participants have an opportunity to share their thoughts, fellowship with other colleagues and to discuss the module's materials in detail. At the end of each workshop, the larger group is reduced to a smaller core group, led by a facilitator in a different room to debrief and discuss. One common principle that the facilitators avoid when assigning the core groups is having department chairs in the same small group as their immediate colleagues. In other words, a junior faculty member would never be a part of the same core group as their chair, thus allowing more of an opportunity for all faculty members to feel comfortable when discussing potentially sensitive topics.

Regarding funding, the college's yearly budget for the SEED program includes National SEED facilitator training $(\$ 4,700$ per facilitator for program and travel), facilitator stipends $(\$ 1,000$ per facilitator per year), facilitator planning retreat $(\$ 500)$, food $(7$ sessions @ $\$ 300$ per session), fall retreat $(\$ 1,500)$, final banquet $(\$ 1,500)$ and supplies $(\$ 300)$. Smaller stipends are offered occasionally for facilitators from past years who lead in-house training sessions. As mentioned above, as the college has started to incorporate more in-house training for new facilitators, some of these expenses will become obsolete.

The program has run for five years and is half-way through its sixth year. Due to COVID-19, during the latter half of the 2019-2020 academic year, the SEED workshops were moved to an online platform. In the following year, the college started the fall semester completely online, and as a result the SEED workshops continued to be held synchronously, though virtually. Interestingly, as noted in the table below, the number of participants more than tripled from the previous year. This shows evidence that perhaps faculty members are more compelled to participate in voluntary diversity training if they can do so from the comfort of their own space. 
TABLE 1

PARTICIPANTS WHO COMPLETED OR ARE CURRENTLY PARTICIPATING IN THE COLLEGE SEED PROGRAM

\begin{tabular}{|l|l|l|l|}
\hline & Facilitators & Faculty & Staff \\
\hline $2016-2017$ & 5 & 24 & 5 \\
\hline $2017-2018$ & 10 & 35 & 24 \\
\hline $2018-2019$ & 5 & 17 & 6 \\
\hline $2019-2020$ & 6 & 21 & 14 \\
\hline $2020-2021^{*}$ & 8 & 29 & 27 \\
Zoom meetings & & 8 international faculty members & \\
\hline Totals & & 134 & 77 \\
\hline
\end{tabular}

* For the first time, the College was able to include international faculty members in the SEED training as a result of the virtual platform.

Pivoting to the demographic make-up of the faculty population, the college boasts 228 full-time faculty members, $52 \%$ female and $48 \%$ female. The ethnic representation of the faculty includes $77 \%$ white, $12 \%$ Asian, 4\% African-American, 4\% Hispanic/Latinx, and 3\% international, multi-ethnic, or unknown (Office of Institutional Effectiveness, 2019). Considering the shift towards a more diverse student population, these same changes are not reflected in the faculty demographics. Regarding faculty participation in the SEED program, $56 \%$ of the 228 faculty members of the college have participated (or are currently enrolled in) the program. As mentioned previously participation is neither required nor incentivized.

After taking a more detailed look at the SEED program and the college demographics, in the next section we discuss the methodology and analytical methods we employ to examine the collective responses of faculty members that have participated in the program between the academic years 2016-2017 and 20192020 with an interest in how the program has impacted their course design and curriculum.

\section{METHODOLOGY AND FRAMEWORK}

As noted in the literature review, many studies have focused on the importance of faculty diversity and inclusion training (Booker, Merriweather \& Campbell-Whatley, 2016; Boysen, 2012; Boysen, Vogel, Cope \& Hubbard, 2009; Caplan \& Ford, 2014; Jones, 2017; Minikel-Lacocque, 2013; Marcus, Mullins, Brackett, Tang, Allen \& Pruett, 2003; Samuels, 2014; Sue, Lin, Torino, Capodilupo \& Rivera, 2009; Torres, HowardHamilton \& Cooper, 2003), on the impact of faculty training on classroom climate (Burnell \& Schnackenberg, 2015; Goldstein Hode, Behm-Morawitz \& Hays, 2018; Jones, King, Nelson, Geller \& Bowes-Sperry, 2013; Rogers-Sirin \& Sirin, 2009), and on the effectiveness of diversity training on personal faculty conviction (Hudson, 2020). While this study confirms and builds on many of the primary findings of these previous studies, it also fills a gap in the literature surrounding diversity and equity training by specifically assessing the effectiveness of SEED training for university faculty. Of particular assistance has been Hudson's 2020 study, as previously mentioned, although our study diverges from hers in methodology, participant pool, and raw data. For this survey, we used a combination of open and closeended questions. We collected faculty responses using a five-point Likert-scale to score feedback, followed by optional short answer questions. We chose Likert-scale questions because we were disseminating our survey right before finals season, so we needed to provide our participants with a survey that was clear, did not require much of a time investment, and would be simpler for us to gather and analyze the data. We offered our participants five answer choices rather than four, allowing them to remain neutral if they chose. We then offered our participants the option to answer a series of open-ended questions, which we approached as qualitative research for several reasons. Open-ended questions allow the community to anonymously speak for itself about the nuanced particularity of their own experience without predetermined variables or questions, and allowed SEED participants to expand on their personal experiences in greater details than Likert-scale questions would allow. This method acknowledges that the lived experiences of 
the participants are complex and helps avoid the assumption of a single objective reality (Padgett, 2012), while allowing the researchers the freedom to pursue depth over breadth in order to understand a specific situation in a specific context (Rubin and Rubin, 2012.) Furthermore, for faculty who feel ill-equipped or uncomfortable discussing diversity and inclusion issues in their pedagogy (Sciame-Giesecke, Roden \& Parkinson, 2009; Tatum, 1992), anonymous open-ended questions allow the respondents to speak freely about their experiences without fear of reprisal or censure.

We sent an email to SEED alumni inviting them to participate in an anonymous online survey related to their experiences (Appendix A). We distributed the ten-question survey to 76 full-time faculty members who completed one of the first three years of the SEED program (2016-2019), and received responses from 44 professors. The first five questions employed the Likert scale ranging from: Strongly Agree, Agree, Neutral, Disagree and Strongly Disagree. The participants were asked to use the scale to gauge their level of agreement with the following statements:

1. After participating in the SEED program, I feel more prepared to address issues of diversity in the classroom.

2. It is important for our College to have ongoing conversations about diversity, equity and inclusion.

3. It is important for faculty to learn about and grow in their understanding of diversity.

4. It is important for faculty to learn about and grow in their ability to teach diverse students.

5. The curricula of a College should include issues of diversity.

As in other studies that have evaluated university faculty responses to college-led diversity workshops (Hudson 2020; Ceo-DiFrancesco et al., 2019), the Likert-scale as a means to collect responses provides a transparent and accessible medium to organize and analyze quantitative data in order to draw conclusions regarding the SEED program and faculty takeaway.

In addition to the Likert-scale questions, the second set of questions were open-ended. The researchers included open-ended questions to allow participants an opportunity to provide unrestrained responses. In analyzing the data, these questions will be relevant for determining trends amongst faculty members in regards to the impact of the program as well as the ways the college can build on or improve the SEED program. The open-ended questions asked faculty to respond to:

6. How has your participation in the SEED program affected...Y Your understanding of diversity, equity and/or inclusion?

7. How has your participation in the SEED program affected... Your perspective on systems of power, privilege and oppression?

8. How has your participation in the SEED program affected...Your course content and/or teaching techniques?

9. How has your participation in the SEED program affected...Your interaction with students?

10. What other feedback would you like to share about the SEED program, diversity-related faculty development, diversity in the curriculum, or teaching diverse students at College?

To code the open-ended questions, we examined the frequency of themes found in participant responses. From these recurring themes, we formed descriptive categories that we will use in the following section to analyze the responses (Rubin and Rubin, 2012; Saldana, 2007; Tufford \& Newman, 2010). Using a survey inclusive of Likert-scale and open-ended questions allows us not only to attain measurable feedback, but to also assess reoccurring themes from the participants.

\section{Ethical Considerations}

The college's Institutional Review Board approved the current research project. Furthermore, all SEED alumni were informed of their right to accept or decline participation in the study. In this context, all participants who submitted responses understood that the researchers would use their feedback to examine the SEED program and its impact on faculty both personally and professionally and that their responses would become part of a research project to be presented at a conference and potentially published. Moreover, the research team reviewed the open-ended questions for accuracy and to ensure the analysis of the data was reflective of appropriate descriptive categories (Creswell, 2013; Rubin \& Rubin, 2016). 


\section{ANALYSIS}

As mentioned in the methodology section, participants used a Likert-scale to respond to the first five questions regarding their experiences and opinions about topics of diversity after completing the SEED program. As reflected below in Table 2, the researchers found that $77.28 \%$ of participants agreed or strongly agreed that they are more prepared to address issues of diversity in the classroom. $97.67 \%$ agreed or strongly agreed that they believe it is important for the college to have ongoing conversations about diversity, equity and inclusion, and $97.73 \%$ agreed or strongly agreed that it is important for faculty to learn about and grow in their understanding of diversity. Finally, regarding the need to include topics of diversity in the college curricula, $95.45 \%$ of SEED alumni agreed or strongly agreed that these types of issues should be a part of student learning.

TABLE 2

ANALYSIS OF SEED ALUMNI SURVEY LIKERT-SCALE QUESTIONS

\begin{tabular}{|l|l|l|l|l|l|}
\hline & $\begin{array}{l}\text { Strongly } \\
\text { Agree }\end{array}$ & Agree & Neutral & Disagree & $\begin{array}{l}\text { Strongly } \\
\text { Disagree }\end{array}$ \\
\hline $\begin{array}{l}\text { 1.After participating in the SEED program, I } \\
\text { feel more prepared to address issues of } \\
\text { diversity in the classroom. }\end{array}$ & $29.55 \%$ & $47.73 \%$ & $18.18 \%$ & $4.55 \%$ & $0 \%$ \\
\hline $\begin{array}{l}\text { 2.It is important for our College to have } \\
\text { ongoing conversations about diversity, equity, } \\
\text { and inclusion. }\end{array}$ & $79.07 \%$ & $18.60 \%$ & $2.33 \%$ & $0 \%$ & $0 \%$ \\
\hline $\begin{array}{l}\text { 3.It is important for faculty to learn about and } \\
\text { grow in their understanding of diversity. }\end{array}$ & $79.55 \%$ & $18.18 \%$ & $2.27 \%$ & $0 \%$ & $0 \%$ \\
\hline $\begin{array}{l}\text { 4.It is important for faculty to learn about and } \\
\text { grow in their ability to teach diverse students. }\end{array}$ & $86.36 \%$ & $11.36 \%$ & $2.27 \%$ & $0 \%$ & $0 \%$ \\
\hline $\begin{array}{l}\text { 5.The curricula of the College should include } \\
\text { issues of diversity. }\end{array}$ & $61.36 \%$ & $34.09 \%$ & $2.27 \%$ & $2.27 \%$ & $0 \%$ \\
\hline *Only 43/44 participants answered & & & & & \\
\hline
\end{tabular}

Thus, after completing the two-semester long SEED program, faculty responses to the Likert-scale questions show that participants mutually agree they are more adequately prepared to face issues of diversity in the classroom (Booker et al., 2016; Ceo-DiFrancesco et al., 2019), to engage in supporting discussions surrounding the topic of diversity in the university setting (Burnell \& Schnackenberg, 2015; Goldstein Hode, Behm-Morawitz \& Hays, 2018; Jones, King, Nelson, Geller \& Bowes-Sperry, 2013; Rogers-Sirin \& Sirin, 2009), as well as in curricular changes (Hudson, 2020), all conclusions supporting the findings of previous studies.

The SEED alumni faculty survey also included five open-ended questions asking for explanations of how participation in the SEED program affected participants personally and professionally, and these questions are where our study contributes to the conversation on the impact of diversity, equality and inclusion campus initiatives. In the subsections below, we present the recurring themes the college faculty mentioned in their responses regarding SEED and the college faculty, SEED and the college classroom, and SEED and the college as an institution. 


\section{SEED and the College Faculty}

Three themes emerged from the open-ended questions in relation to faculty participation in the SEED program. First, SEED alumni noted the collegiality and mutual appreciation amongst like-minded faculty who were a part of the program. To this point, one faculty member commented, "SEED has impacted how I speak about these issues with my colleagues and in more informal settings where students aren't involved. SEED has given us a common language to discuss power and oppression in a variety of settings, and it has given me the gift of knowing who my allies on campus are." Another one mentioned discussing difficult questions regarding diversity and inclusion that, "[i]t was nice to see that others care about this topic too. Sometimes it feels like you are alone, but there are others trying to make the institution a better place."

The second theme that faculty mentioned was an increased self-awareness and understanding of their own privilege. This was exemplified when one faculty member commented, "I am more aware of my own blind spots, and I have more respect for why issues that seem unimportant to me are critically important to others-- sometimes it's hard to see the impact of the privileges you have." Regarding the recognition of privilege, one SEED alumni noted about interactions with students that, "I am more aware of my own privilege and have demonstrated more grace towards students with less privilege." Gay (2010) affirms that personal growth produces an increase in knowledge and skills and changes attitudes.

Lastly, SEED participants pointed out they are more aware of the hierarchies and systems of power that exist at the institutional level, because of their participation in SEED. For instance, one participant mentioned that, "I have learned how to see interactions with colleagues and students, both in meetings and in the classroom, through a lens of how different experiences of power and privilege may affect these interactions. It has made me much more intentional about how I construct and run meetings and the way in which I participate in meetings." In addition to the hierarchies of the university as an institution, other SEED alumni pointed out how the program has helped them to have more compassion for colleagues of color, "I am more aware of who talks at meetings, and when I talk. I am more aware of active systems of white supremacy. I have a better understanding of what my colleagues of color face on a daily basis."

Together, these themes illuminate some of the collective responses that faculty who have completed the SEED program put forth regarding their personal growth and self-understanding, as well as their experiences with other colleagues and students. The next section will point out salient themes related to the SEED program and its effect on faculty members in the classroom.

\section{SEED and the College Classroom}

In addition to asking open-ended questions regarding faculty member's reaction to their personal growth and the ways the SEED program influenced them personally and professionally, the researchers were interested in how the program affected the college's classroom and curriculum design. Some of the prominent themes related to curriculum changes were the use of more inclusive terminology to discuss issues of diversity and inclusion, the use of SEED training materials as pedagogical tools and more consideration for topics of diversity as they relate to interacting with students in the classroom.

The faculty remarked that the SEED program introduced them to a more inclusive vocabulary, which many of them use as a tool to better articulate classroom discussions that touch on topics of diversity and inclusion. For example, one faculty member commented that, "SEED has changed the way that I talk about these issues, the way that I teach - both my pedagogy and course content. SEED has reminded me that my attention to the details of emails, in-class interactions, etc., have enormous significance for my students, my colleagues, and myself." Another colleague shared this opinion noting that, "I am more conscious of how I address my students, how I seek to include all of them, and how I choose my words." Ultimately, it appears that faculty engagement with inclusive vocabulary to discuss questions of diversity in the classroom has aided SEED alumni in feeling more comfortable approaching these topics. As one faculty member pointed out about the program, "I am more equipped to lead conversations on tough topics." To this point, Gurin et al. (2002) mention that greater awareness of linguistic choices amongst faculty members heightens their sensitivity to using more inclusive language in their lectures.

In addition to the use of more inclusive vocabulary in the classroom, another prevalent theme related to changes made by SEED alumni resulting from the program, was the use of various pedagogical tools 
modeled in the SEED workshops. Many faculty members mentioned using these materials in their classrooms. Related to class texts and readings, two faculty members noted how they refreshed their materials. One professor commented, "SEED compelled me to change my syllabus to include a global representation, to change my textbook from one that was deliberately Eurocentric to one that is global in its approach. SEED has prompted me to adopt serial testimony, pair-share, timed responses, and more equitable activities in my classroom." Another one affirmed,

I have included both content and tools in my courses. I use several of SEED tools to create a more democratic sharing of "airspace" as well as to increase personal engagement with course material. I have also added some readings from non-traditional, marginalized voices, which has 1) enhanced course discussion for ALL students and 2) has been particularly meaningful for multiple students of color who have specifically thanked me for including these readings in class.

In addition to a change in text materials, another participant remarked how they make it a point to incorporate voices and faces that are more diverse into their PowerPoints and lecture materials. They commented, "I made an effort to discuss diversity more often, have ensured that all lectures and photos on my PowerPoints include diverse images, and I am more aware of my own misconceptions around my expectations regarding the capabilities of my college students."

Outside of the SEED program's impact on college classroom texts, another prominent theme related to the classroom noted by faculty is a more compassionate consideration for their diverse student groups. For example, one faculty member stated that the program changed their interaction with students in, "[n]umerous ways - I think about who I call on, who I engage with and how I create opportunities for students to learn from one another. I also focus a lot more on creating a welcoming community." Another professor affirmed, "I consider the social location of students more. I consider how my assignments or inclass questions make assumptions about the backgrounds of students that may not be applicable." Thus, it appears from engaging with the salient themes relating to the SEED program and faculty application to the Seaver classroom that participants have updated their use of terminology in the classroom to reflect inclusive vocabulary. Furthermore, faculty members have also begun to consider diversity as an important factor when choosing course materials, as well as the types of images they show in the classroom.

\section{SEED and the Institution}

Lastly, the open-ended questions pointed to overall concerns, suggestions and takeaways that participants had after completing the SEED program. As pointed out in the previous sub-sections, faculty members reported an overall satisfaction with the program as a means to aid them in establishing connections with other like-minded colleagues and an increased self-awareness and understanding of power dynamics at the college level. Outside of their personal engagement with the program, on the professional front, faculty members commented they feel more equipped to lead classrooms with a variety of students and are better prepared to have discussions dealing with topics of diversity and inclusion. They additionally noted that the SEED program has made them more aware of the types of resources, images and texts they include in their lectures and mention that they take strides to be mindful of these factors when preparing materials and interacting with students. However, participants also shared some reflective concerns related to the SEED program in light of its location at a College campus, and furthermore, there was some apprehension about the buy-in of upper administration and their participation in the program if it is to have any success at the institutional level. For instance, one faculty member remarked about the upper administration, "[w]hile I am encouraged by the level of participation by faculty and staff, I wonder how SEED is viewed by upper administration and even trustees." Along the same lines another SEED participant commented, "[b]ecause [the college's] systemic sexism pervades all levels of operations, I am hopeful that administrators (mostly white males) will enroll in this course, perhaps along with faculty... [h]owever, I just wanted to mention as well that the program should be extended to our colleagues in other Schools [at 
the university]." Other faculty members expressed concern for their apprehension to express opinions that might differ from those of others, as well as the welfare of faculty members of color at the college ,

While I very much enjoy my colleagues, I wouldn't say my experience was particularly enriching. SEED felt more like an indoctrination camp than a place to *freely* explore these difficult topics, especially if one would have a different opinion than the majority. Ironically, it didn't feel like a safe place (to have a different thought or opinion) - it felt like everyone was supposed to arrive at the same thought/place.

Related to concern for faculty members of color, some participants mentioned their concern for a more supportive community. One participant noted, "I believe we have come a long way with SEED in helping our white faculty understanding systems of power and privilege. I am concerned that we still need to be doing more for our faculty of color to create a supportive community." Affirming this point, one faculty member of color expressed her challenges with participating in the program,

$[\mathrm{m}] \mathrm{y}$ sense is that power is largely blind and that those who need to be in SEED training are not and that those who already recognize its importance are. I personally found SEED training to be challenging because, as a woman of color, I became even more self-conscious about my liminal status and started to second-guess my interactions with others. That said, I'm glad that our College is supporting this program because of what it says about institutional priorities. On a personal level, however, my own participation was more of an act of service to others than a benefit to myself.

In addition to the SEED program and its relation to faculty of color, other faculty members commented on the need to apply the practices taught in the SEED program to the university's hiring and student evaluation practices. For example, a SEED participant mentioned that,

We need to interrogate our practices around faculty hiring and evaluation. For example, study after study has shown the bias inherent in student evaluations, yet we still place a disproportionate weight on them. We do not follow a clear evaluation protocol for hiring. Aside from ensuring that there is a [representative of University religious affiliation] candidate and a "diverse" candidate, we don't seem to have any clear strategies in place to address systemic bias.

Hence, the comments above reflect faculty perceptions of SEED pedagogies, and how they are potentially limiting for the institution. Some faculty members pointed out the lack of participation from upper administration officials. Furthermore, others commented on the lack of integration of these pedagogies into the college's consideration of how biased student evaluations impact faculty members, the hiring process at the university, and its consideration of faculty of color.

\section{DISCUSSION AND CONCLUSIONS}

After analyzing the responses of the college's faculty about their participation in the SEED program, the researchers have a more holistic understanding of the personal and professional benefits of the training. We also recognize some of the difficulties and challenges faced by the faculty as they reexamined their cultural narratives and personal beliefs, as well as their interaction with students and the classroom materials they present. As scholars Cranton (2016) and Donaday (2002) point out, the discomfort, stemming from engagement with critical pedagogies can lead to transformative learning.

In relation to the goals of the SEED program, it was proposed as a solution to provide faculty with training to address issues of diversity and inclusion. In this context, the college has provided a space for faculty members to examine and interact with unique and individual stories related to the American social 
system. The SEED program, according to most faculty participants, has reached this goal by further educating and clarifying for its participants how these institutional systems affect interactions amongst peers, colleagues and students in a university setting.

In calling attention to the power structures at play in institutional contexts, the SEED program also afforded faculty members a space to participate with peers in face-to-face conversations regarding issues of social justice, thus building community. Hence, the SEED workshops, as commented by participants, gave an opportunity to create alliances and comradery amongst faculty members across various disciplines at the college. This space of fellowship is not only a personal benefit but also a pedagogical advantage for the college classroom and the university at large. As Anderson (1994) affirms, a sense of community amongst faculty members during training programs is pertinent to their learning experience.

In light of the 2015 on-campus protests of the college's students, and their demands that students, faculty and staff complete cultural sensitivity and diversity training, the college's Diversity Council recognized the need for a program that could provide a collaborative and active learning environment. The SEED program has successfully supplied experiential learning to participants based on personal experiences as a means to examine critical pedagogies. Though SEED program participants engaged with traditional learning materials such as scholarly articles, clips and videos, the program also included active learning activities, discussions with different groups (small and large), as well as critical and reflective tasks. These unique and group building methodologies employed by the SEED program encourage faculty to self-reflect and address their own biases, while also providing tools and techniques that can translate into the classroom.

The positive feedback garnered from faculty in regards to their participation in the SEED program points out the need to interconnect the university's diversity and inclusion goals for its employees with the institutional agenda related to hiring practices and student's evaluation of diverse and minority faculty members. Related to maintaining the connection between faculty members and their training, Anderson (2008) proposes that universities should consider workshops that strengthen and inspire faculty collaborations and fellowship across the university, as opposed to the traditional one-time workshops. With an effort in continuing the dialogue fostered in the SEED program. Currently, two SEED alumnus (one faculty member and one staff member) lead and coordinate the SEED 2.0 workshops, which occur twice per semester during the academic school year. SEED 2.0 directly addresses the recommendations of faculty members, who advocate for the continuation of addressing critical issues on campus,

I still maintain that SEED is one of the most important, transformational, challenging, meaningful programs in which I have ever participated. I am so glad that our College has adopted this program. While I do believe that the program would be beneficial for every faculty member, I also understand and appreciate the decision to make participation in the program voluntary. My hope is that the work of SEED will continue, as the name implies, by creating a campus-wide "root system" that will allow a more inclusive pedagogy to flourish in all classrooms, offices, and meeting spaces at College...

One of the most surprising conclusions from this study is the success of SEED as an online option. For the school year 2020-2021, the SEED workshops started completely online, and enrolled more than triple the number of participants from the previous year. The tripling of enrollment is particularly meaningful given increased faculty stress and anxiety during the COVID-19 pandemic (Flaherty, 2020), especially for women and women of color (Kramer, 2020), and the cloud of general anxiety over the future of the higher academic workplace (Belkin, 2020). While the reasons for this increase might be due to unique events (the pandemic, a call for increased diversity and inclusion training as a result of the protests of the summer of 2020), this increase shows evidence that perhaps faculty members are more compelled to participate in voluntary diversity training if they can do so virtually, with the critical added benefit of improved access for disabled attendees, and the budget-saving outcome of administration not needing to provide food and refreshments for participants. 
Thus, we conclude that the SEED program at the college, although not without some challenges, is a valuable and enriching program that encourages and allows space for the examination of cultural narratives and social systems in a collegial and interactive context.

\section{LIMITATIONS AND FUTURE RESEARCH}

Since the college's faculty is primarily representative of a predominantly white faculty group, the findings of the present article may not be reflective of other universities with a different faculty demographic. In addition, the use of the Likert-scale and open-ended questions to form the SEED Alumni survey solicited self-reported answers. In this context, it could be advantageous to compare the current findings with an observational component. Asking tenured faculty members for their buy-in allowing researchers to observe their classes before and after completing the SEED program could add another analytical factor to consider as administrators prepare for future diversity training (Sciame-Giesecke et al., 2009).

Furthermore, in the current study, we only consider the impact of the SEED program on the college faculty. Since the college has begun to offer the program to staff members, future research could examine the reception of the program amongst staff members and how they apply SEED pedagogies to their work contexts. Other colleges at the institution have also started to implement the SEED program. Thus, it would additionally be worth exploring if faculty members in other colleges express similar or dissimilar reactions to the training. Furthermore, as a result of the COVID-19 pandemic, the SEED program has continued virtually since March 2020. Fall 2020 was the first virtual offering of SEED, currently held synchronously on Zoom. The 2020-2021 academic year boasts the highest number of participants the program has enjoyed since its inception. In light of this information, it would be advantageous to investigate if virtual diversity training would appeal more largely to faculty populations due to more accessibility, while maintaining the synchronous nature of the training.

\section{REFERENCES}

Ancis, J.R., Sedlacek, W.E., \& Mohr, J.J. (2000). Student perceptions of campus cultural climate by race. Journal of Counseling and Development, 78, 180-185.

Anderson, J.A. (1994). Examining teaching styles and student learning in Science and Math classrooms. In M.M. Atwater (Ed.), Multicultural education: Inclusive of all (pp. 93-106). Athens: University of Georgia Press.

Banks, J.A. (2006). Cultural diversity and education: Foundations, curriculum, and teaching (5th ed.). Boston: Pearson Education.

Belkin, D. (2020, December). Hit by Covid-19, Colleges Do the Unthinkable and Cut Tenure. The Wall Street Journal. Retrieved from https://www.wsj.com/articles /hit-by-covid-19-Colleges-do-theunthinkable-and-cut-tenure-11607250780

Bell, L.A., \& Griffin, P. (2007). Designing social justice education courses. In M. Adams, L.A. Bell, P. Griffin (Eds.), Teaching for Diversity and Social Justice (2nd ed., pp. 67-87). New York: Routledge.

Blakeney, A.M. (2005). Antiracist Pedagogy: Definition, Theory, and Professional Development. Journal of Curriculum and Pedagogy, 2(1), 119-132.

Booker, K.C., Merriweather, L., \& Campbell-Whatley, G. (2016). The Effects of Diversity Training on Faculty and Students' Classroom Experiences. International Journal for the Scholarship of Teaching and Learning, 10(1). doi: 10.20429/ijsotl.2016.100103

Clark, C. (2011). Diversity initiatives in higher education: Just how important "is" diversity in higher education? Multicultural Education, 19(3), 57-59.

Consoli, M.L.M., \& Marin, P. (2016). Teaching diversity in the graduate classroom: The instructor, the students, the classroom, or all of the above? Journal of Diversity in Higher Education, 9(2), 143157. doi: $10.1037 / \mathrm{a} 0039716$ 
Cranton, P. (1996). Professional development as transformative learning: new perspectives for teachers of adults. San Francisco, CA: Jossey-Bass.

Creswell, J.W., \& Poth, C.N. (2018). Qualitative inquiry and research design: Choosing among five approaches. Los Angeles, CA: Sage.

Deshmukh Towery, I., Oliveri, R., \& Gidney, C.L. (2007). Peer-led professional development for equity and diversity: A report for teachers and administrators based on findings from the SEED Project (Seeking Educational Equity and Diversity). Cambridge, MA: The Schott Foundation for Public Education.

DiFrancesco, D., Kochlefl, M., \& Walker, J. (2019). Fostering Inclusive Teaching: A Systemic Approach to Develop Faculty Competencies. Journal of Higher Education Theory and Practice, 19(1). doi: 10.33423/jhetp.v19i1.666

Dobbin, F., \& Kaley, A. (2016, July-August). Why diversity programs fail. Harvard Business Review. Retrieved from https://hbr.org/2016/07/why-diversity-programs-fail

Donadey, A. (2002). Negotiating Tensions: Teaching About Race Issues in Graduate Feminist Classrooms. NWSA Journal, 14(1), 82-102. doi: 10.2979/nws.2002.14.1.82

Flaherty, C. (2020, November). Faculty Pandemic Stress Is Now Chronic. Inside Higher Ed. Retrieved from https://www.insidehighered.com/news/2020/11/19/faculty-pandemic-stress-now-chronic

Garvey, J.C., \& Rankin, S.R. (2015). Making the Grade? Classroom Climate for LGBTQ Students Across Gender Conformity. Journal of Student Affairs Research and Practice, 52(2), 190-203. doi: 10.1080/19496591.2015.1019764

Gay, G. (2010). Culturally responsive teaching: Theory, research, and practice (2nd ed.). New York: Teachers College Press.

Gordon, B. (2015). SEED as Change Agent - Personal, Institutional and Community. National SEED Project. Retrieved January 20, 2020, from https://nationalseedproject.org/Leader-Essays/seed-aschange-agent-personal-institutional-and-community

Hagan, M., \& Mcglynn, C. (2004). Moving barriers: Promoting learning for diversity in initial teacher education. Intercultural Education, 15(3), 243-252. doi: 10.1080/1467598042000262545

Harrison, S., \& Killpatrick, K. (2019, December 19). Personal interview with Kindalee De Long.

Harwell, M. (2015, November 13). Pepperdine Students Protest in Solidarity with Mizzou. Pepperdine Graphic. Retrieved from pepperdine-graphic.com

Hicks, M., Smith, D.R., Winton, S., \& Wood, D.R. (2008). SEEDs of Promise: Transformative Learning Communities for Diverse Schools. Multicultural Perspectives, 10(1), 30-34. doi:10.1080/15210960701869512

Horsford, S.D., Grosland, T., \& Gunn, K.M. (2011). Pedagogy of the Personal and Professional: Toward a Framework for Culturally Relevant Leadership. Journal of School Leadership, 21, 582-606.

Humphreys, D. (1997). General Education and American Commitments: A National Report on Diversity Courses and Requirements. Washington, D.C.: AAC\&U.

Hurtado, S., Mayhew, M.J., \& Engberg, M.E. (2012). Diversity courses and students' moral reasoning: A model of predispositions and change. Journal of Moral Education, 41(2), 201-224. doi:10.1080/03057240.2012.670931

Kishimoto, K. (2018). Anti-racist pedagogy: From faculty’s self-reflection to organizing within and beyond the classroom. Race Ethnicity and Education, 21(4), 540-554. DOI: $10.1080 / 13613324.2016 .1248824$

Kramer, J. (2020, October). The Virus Moved Female Faculty to the Brink. Will Universities Help? New York Times. Retrieved from https://www.nytimes.com/2020/10/06/science/covid-universitieswomen.html

Lewis, W.B. (2010, April 15). Inclusive Excellence and the Role of Faculty. Diverse: Issues in Higher Education, 27(5), 20-20.

Mahabir, H. (2015). Making Space, Taking Time, Sharing Power. National SEED Project. Retrieved January 20, 2020, from https://nationalseedproject.org/Leader-Essays/making-space-taking-timesharing-power 
McCauley, C., Wright, M., \& Harris, M.E. (2000). Diversity workshops on campus: A survey of current practice at U.S. Colleges and universities. College Student Journal, 34(1), 100-114.

McFarland. (2019, May 22). The Condition of Education 2019. Retrieved from https://nces.ed.gov/pubsearch/pubsinfo.asp?pubid=2019144

Moriña, A., Cortés-Vega, M.D., \& Molina, V.M. (2015). Faculty training: An unavoidable requirement for approaching more inclusive university classrooms. Teaching in Higher Education, 20(8), 795-806. doi:10.1080/13562517.2015.1085855

National Center for Education Statistics. (n.d.). The NCES Fast Facts Tool provides quick answers to many education questions. Retrieved from https://nces.ed.gov/fastfacts/index.asp?faq=FFOption5

O'Hara, S., \& Pritchard, R.H. (2008). Meeting the Challenge of Diversity: Professional Development for Teacher Educators. Part of the Special Issue. Communities of Practice, 35(1), 43-61.

Pepperdine University Factbook. (2019). Office of Institutional Effectiveness. Retrieved from https://www.pepperdine.edu/oie/institutional-research/factbook.htm

Potthoff, D., Dinsmore, J.A., \& Moore, T.J. (2001). The diversity cohort-A professional development program for College faculty. The Teacher Educator, 37(2), 145-156. doi: $10.1080 / 08878730109555288$

Prater, M., \& Devereaux, T. (2009). Culturally responsive training of teacher educators. Action in Teacher Education, 31(3), 19-27.

Rubin, H.J., \& Rubin, I.S. (2016). Qualitative interviewing: The art of hearing data. Los Angeles: Sage.

Sciame-Giesecke, S., Roden, D., \& Parkison, K. (2009). Infusing diversity into the curriculum: What are faculty members actually doing? Journal of Diversity in Higher Education, 2(3), 156-165. doi: $10.1037 / \mathrm{a} 0016042$

Sue, D.W., Lin, A.I., Torino, G.C., Capodilupo, C.M., \& Rivera, D.P. (2009). Racial microaggressions and difficult dialogues on race in the classroom. Cultural Diversity \& Ethnic Minority Psychology, 15(2), 183-190. doi: 10.1037/a0014191

Tatum, B. (1992). Talking about Race, Learning about Racism: The Application of Racial Identity Development Theory in the Classroom. Harvard Educational Review, 62(1), 1-25. doi: 10.17763/haer.62.1.146k5v980r703023

Tufford, L., \& Newman, P. (2010). Bracketing in Qualitative Research. Qualitative Social Work: Research and Practice, 11(1), 80-96. doi: 10.1177/1473325010368316

U.S. Department of Education. (2016). Advancing Diversity and Inclusion in Higher Education. Retrieved from https://www2.ed.gov/rschstat/research/pubs/advancing-diversity-inclusion.pdf

Waterman, S.J. (2013). Using theory to tell it like it is. The Urban Review, 45, 335-354. http://dx.doi.org/10.1007/s11256-012-0233-2 